Canadian Journal of Higher Education

Revue canadienne d'enseignement supérieur

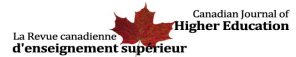

\title{
Book review of " Canadian Universities in China's Transformation: An Untold Story"
}

\section{Rahul Kumar}

Volume 48, Number 1, 2018

URI: https://id.erudit.org/iderudit/1050847ar

DOI: https://doi.org/10.7202/1050847ar

See table of contents

Publisher(s)

Canadian Society for the Study of Higher Education

ISSN

2293-6602 (digital)

Explore this journal

Cite this review

Kumar, R. (2018). Review of [Book review of " Canadian Universities in China's Transformation: An Untold Story"]. Canadian Journal of Higher Education /

Revue canadienne d'enseignement supérieur, 48(1), 148-150.

https://doi.org/10.7202/1050847ar

Copyright (c) Rahul Kumar, 2018

Attribution-NonCommercial-No Derivative Works 2.5 Canada
This document is protected by copyright law. Use of the services of Érudit (including reproduction) is subject to its terms and conditions, which can be viewed online.

https://apropos.erudit.org/en/users/policy-on-use/ 
Canadian Journal of Higher Education Revue canadienne d'enseignement supérieur

Volume 48, No. 1, 2018, pages 148 - 150

\title{
Book Review / Compte rendu
}

\author{
Hayhoe, R., Pan, J., \& Zha, Q. (Eds.) (2016). Canadian Universities in Chi- \\ na's Transformation: An Untold Story. Montreal: McGill-Queen's University \\ Press. Pages: 362. Price: $\$ 37.95$ CDN (paper).
}

Reviewed by Rahul Kumar, Assistant Professor, Brock University

Martin Luther King Jr.'s assertion that we are not only makers of history but also made by it is true in this edited volume by Hayhoe, Pan, and Zha. In this compiled book, Canadian and Chinese contributors have recollected and described how the partnership between Canada and China in the post-secondary sphere started, how it was nourished and tended by academics from both sides, and how it has blossomed to its current state.

When bilateral partnerships between nations are contemplated, seldom are the roles of universities from other countries in the planning, promotion, and development of such partnerships recognized for the foundational part they perform. And yet, these are precisely the kinds of initiatives between Canada and China that this edited volume reveals. Ruth Hayhoe, Julia Pan, and Qiang Zha inform us that the cooperation between Canadian and Chinese universities dates to 1983 and that such a partnership was the first between China and a Western nation. It started at a time when billboards in China were urging its citizens to be cautious of foreign influences (Bild, chapter 3). From those beginnings, such partnerships have blossomed to the third most lucrative set of partnerships for Canada. This was made possible because there were efforts made by people in various sectors. In keeping with this reality, diverse experiences by scholars and non-academic dignitaries alike are captured here. The overall tone of this volume is celebratory, highlighting that this partnership has been mutually beneficial to universities in both countries.

The book should be seen as comprised of six distinct sections. The first chapter lays out the larger context, the impetus for the book, and reports on the findings of a research study conducted by Hayhoe, Pan, and Zhan. It should be viewed as an essential section of the book. Other chapters in the book may fail to impress the reader who does not understand the larger and complex landscape that this first chapter offers. The 12 chapters that follow the first are organized into four separate parts. The first part, comprised of two chapters, explicates the political and socio-cultural context of change. The second 
part, comprised of three chapters, moves from the political to the economic dimension of Canada-Chinese partnerships. The third part, comprised of three chapters, highlights the engineering and environment based collaborations supported by the Canadian International Development Agency. The fourth part tackles education and equity in four chapters. The authors of these chapters were all select Canadian and Chinese presenters at the Canada-China conference held in May, 2014 at Tsinghua University in Beijing. The last distinct section, although the editors of the book do not classify it as such, is a final chapter that includes contributions from presenters at the Canada-China conference who did not contribute individual chapters to this edited volume. This chapter also speculates as to future directions of the burgeoning relationship between Canada and China.

The breadth of topics covered is vast and provides sufficient variety for both new scholars as well as seasoned veterans who are looking at how various developments across several fields in cooperation between Canadian and Chinese universities evolved. How the fields of medicine, nursing, agriculture, engineering, urban infrastructure, environment, education, and minority cultures have benefitted from the partnership is explicated. The question of whether the benefit was equally shared between the two countries is tactfully addressed. Several authors carefully posited that this partnership has enriched and benefited both countries at different times. In the initial stages of partnership, contributions from Canadian universities and its scholars were proportionally larger than their Chinese counterparts, but as the partnership has expanded, Chinese contributions have been "invaluable" (Beamish, chapter 6). By presenting a balanced, symbiotic advantage to both Canadian and Chinese universities, both the authors and editors deserve the readers' appreciation.

Given that the thrust of this book is to enlighten the reader/educator on the history of bi-lateral partnerships between Chinese and Canadian universities, the issue of objectivity is a moot point. However, in several empirical works where the research design of the studies undertaken by authors is explained (e.g., chapter 5), readers' confidence in assertions is preserved.

As with most edited volumes, the individual style of each chapter varies considerably. Some chapters are descriptions of research studies, while others are reflective pieces. Overall, the book has a congratulatory quality and identifies great accomplishments for both the universities and countries because of partnerships between Canadian and Chinese universities. This does not mean that impediments in this progression are concealed, but with the hindsight of known outcomes, they are presented favourably.

The gradual evolution of bilateral university partnerships has been marked by numerous agencies in both China and Canada. Their internal workings and its impact on partnerships with regard to knowledge production, application, and impacts are explained in the book, and, as a result, the growth in the post-secondary education sector of China is better understood.

I was dubious when I started to read this book because often historical narratives are full of chronological progressions of policy development that fail to convey how practices changed. This volume, however, presented practical examples that enlivened what could easily have been stale reports of policy adoption. It gains trustworthiness by disclosing and explaining missteps and set-backs within the local cultural context that happened through the course of nearly 35 years. 
As China continues to grow and evolve and becomes an exporter of education as opposed to an importer, the role that universities will play will need to be recalibrated. This dynamic configuration necessitates that old linkages be examined and periodically reviewed with an aim to change, and universities in both countries should not only create a road map for this but also preserve the memory and know-how of how things evolved. This book is just one such record. It informs the reader of the aspirations, climate, challenges, pitfalls, and opportunities past and present that brought the Canadian-Chinese partnership about and speculates as to where it will go in the future.

With an increasing number of Chinese students attending Canadian universities for both undergraduate and graduate programs coupled with the continuing decline in domestic enrolments, the reliance of our post-secondary and tertiary education systems on students from China is well acknowledged and understood. Many of us who teach in such programs might be unaware of the rich history of partnership, mutual learning, and growth that has resulted because of the partnership. This book endeavours to bridge the historical knowledge gap. The subtleties of what it means to interact, teach, learn, and participate across cultural divides, at every level - students, professor, and administrator - across different disciplines are revealed. People in both Canadian and Chinese higher education involved in this bi-lateral relationship would do well to engage with this insightful text. 